\title{
Chapter 6 \\ Facilitating the Movement of Qualified Dental Graduates to Provide Dental Services Across ASEAN Member States
}

\author{
Suchit Poolthong and Supachai Chuenjitwongsa
}

\begin{abstract}
The Association of Southeast Asian Nations (ASEAN) is a political and economic organization of ten countries located in Southeast Asia. Its one purpose is to promote a free trade area in services among member states. Dentistry is one sector subjected to the free movement policy in which dental practitioners can migrate freely across ASEAN to provide dental services. ASEAN policies and strategies to facilitate the free movement of dental professionals have been developed since 2009. To ensure that dental graduates from all dental schools across ASEAN possess comparable standards of practice, harmonization of undergraduate dental education across ASEAN was announced in 2015. Currently, ASEAN is focusing on developing common competencies for its dental graduates. To maximize the free movement, ASEAN dental education development will work toward developing curriculum guidelines and quality assurance for ASEAN undergraduate dental curricula as well as educational and academic development for ASEAN dental schools and staff.
\end{abstract}

Keywords Free movement of dental professionals • Harmonizing undergraduate dental education - ASEAN dental graduates

\footnotetext{
S. Poolthong

Faculty of Dentistry, Department of Operative Dentistry, Chulalongkorn University, 254 Phayathai Road, Bangkok 10100, Thailand

S. Chuenjitwongsa $(\bowtie)$

Faculty of Dentistry, Department of Biochemistry, Chulalongkorn University, 254 Phayathai Road, Bangkok 10100, Thailand

e-mail: supachai.c@chula.ac.th 


\subsection{Formation of ASEAN to AJCCD}

The Association of Southeast Asian Nations (ASEAN) is a political and economic organization of ten countries located in Southeast Asia: Brunei Darussalam, Cambodia, Indonesia, Laos PDR, Malaysia, Myanmar, the Philippines, Singapore, Thailand, and Vietnam. Its aims include accelerating free trade area among its member states, protection of regional peace and stability, and opportunities for member countries to discuss differences peacefully. In 1995, ASEAN Framework Agreement on Services (AFAS) was established and signed by ASEAN Economic Ministers. Main purposes are to enhance cooperation in services among member states, eliminate substantially restrictions to trade in services, and liberalize trade in services with the aim to realizing a free trade area in services within ASEAN member states. Later on, Coordinating Committee on Services (CCS) was established on its purpose to undertake service integration initiatives within six service sectors, and one sector was healthcare services. Healthcare Services Sectoral Working Group (HSSWG) was then initiated to discuss matters pertaining to facilitation and cooperation within three healthcare professions, and dental profession was one of them. Finally, ASEAN Joint Coordinating Committee on Dental Practitioners (AJCCD), a committee under the HSSWG, was started to facilitate cooperation on Mutual Recognition Arrangement (MRA) for dental practitioners.

\subsection{MRA for Free Flow of Services and Professionals}

The MRA on dental practitioners was finally signed in February 2009 and planned for implementation in 2015. Its objectives are to facilitate mobility of dental practitioners within ASEAN, enhance exchange of information and expertise on standards and qualifications, promote adoption of best practices for professional dental services, and provide opportunities for capacity building and training of dental practitioners. According to the mobility of dental practitioners within ASEAN, there is a concern on the standard of dental services by dentists across the ASEAN. With this regard, harmonization of undergraduate dental education in order to create comparable dental curricula of all dental schools in ASEAN member states is necessary.

ASEAN MRA on dental practitioners was first established in Singapore in 2008. It has been the issue of discussion in the AJCCD meeting ever since. In the MRA, it was stated that this MRA would be discussed for improvement and be revised officially every 5 years. The detail of MRA consists of ten articles [1]. A summary of ten MRA articles is provided in Table 6.1.

For the content of MRA, an introduction provides some basic understanding and terminologies including objectives of AFAS, vision of ASEAN, and some notes regarding level of recognition on education and certification granted in other 
Table 6.1 A summary of ten MRA articles

\begin{tabular}{|c|c|}
\hline Article & Summary \\
\hline 1 & $\begin{array}{l}\text { Outlining the four objectives of the MRA: (1) to facilitate mobility of dental } \\
\text { practitioners within ASEAN, (2) to exchange information and enhance cooperation in } \\
\text { respect of mutual recognition of dental practitioners, (3) to promote adoption of best } \\
\text { practices on standards and qualifications, and (4) to provide opportunities for capacity } \\
\text { building and training of dental practitioners. }\end{array}$ \\
\hline 2 & $\begin{array}{l}\text { Providing definitions of professional terminologies used in dental services and the } \\
\text { names of those authorized organizations, namely, Professional Dental Regulatory } \\
\text { Authority (PDRA). The PDRA is responsible for dental regulations in their own } \\
\text { countries. Those PDRAs vary from Medical Board, Medical Council, Dental Council, } \\
\text { and Professional Regulation Commission to Ministry of Health. Majorities are for } \\
\text { Dental Council and Ministry of Health. }\end{array}$ \\
\hline 3 & $\begin{array}{l}\text { Explaining recognition and eligibility of foreign dental practitioners in host countries. } \\
\text { The foreign dental practitioners can apply for registration in the host country in } \\
\text { accordance with its domestic regulations. With these regulations, they generate } \\
\text { limitations which may not strongly facilitate free flow of dental practitioners such as } \\
\text { the nationality issue and the examination using local languages. Though English is } \\
\text { used as a common language in ASEAN, local languages play important role in the } \\
\text { eligibility to apply for registration in many countries especially the countries outside } \\
\text { the commonwealth. }\end{array}$ \\
\hline 4 & $\begin{array}{l}\text { Defining roles of PDRA and its duties including: to evaluate qualification, to impose } \\
\text { other requirements where applicable, to grant recognition and register eligibility to } \\
\text { practice in the host country, to monitor the compliance of foreign dental practitioners } \\
\text { in order to conform with the domestic regulations, and to take action in case one fails } \\
\text { to practice under domestic regulation. }\end{array}$ \\
\hline 5 & $\begin{array}{l}\text { An agreement from all member states indicating that they will not reduce, eliminate, } \\
\text { or modify power and authority of PDRA. }\end{array}$ \\
\hline 6 & $\begin{array}{l}\text { Explaining about the establishment of AJCCD as a working group under } \\
\text { HSSWG. The AJCCD committee comprises two representatives from each ASEAN } \\
\text { country. The AJCCD's important role is to facilitate the implementation of MRA } \\
\text { through better understanding of domestic regulation. AJCCD also encourages } \\
\text { information exchange among all members and will review the MRA every } 5 \text { years if } \\
\text { necessary. }\end{array}$ \\
\hline 7 & $\begin{array}{l}\text { Discussion about the possibility of mutual exemption where each PDRA has } \\
\text { responsibility to protect health, safety, environment, and welfare of the community } \\
\text { within its authority. }\end{array}$ \\
\hline 8 & $\begin{array}{l}\text { Containing the critical issue of dispute settlement. In order to avoid conflict, every } \\
\text { attempt through communication, consultation, and cooperation is expected to } \\
\text { mutually satisfy any matter that might affect the implementation of the MRA. }\end{array}$ \\
\hline 9 & $\begin{array}{l}\text { Stating about amendment that can be done through only mutual written agreement by } \\
\text { the representatives of all member states. However, the PDRA can be done by its own } \\
\text { country representative regardless of other members' agreements. }\end{array}$ \\
\hline 10 & $\begin{array}{l}\text { Representing the final provisions that was agreed for the deferment of the MRA, if } \\
\text { desired, by any member to be informed within } 6 \text { months after MRA signing. }\end{array}$ \\
\hline
\end{tabular}

ASEAN countries as well as their expectation from the MRA to facilitate free flow of dental practitioners across the region. This is to form a highly competitive ASEAN economic region resulting in free flow of goods, services and investment, 
equitable economic development, reduced poverty and socioeconomic disparities, and enhanced political as well as economic and social stability. One part of free flow of goods, services, and investment is a free flow of dental professionals and dental services. The expected outcomes of the MRA are to strengthen professional capabilities by promoting flow of relevant information and exchanging expertise, experiences, and best practices suited to the specific needs of ASEAN member states.

\subsection{Impact on Dental Education}

To achieve high standard dental services from new dental graduates across the ASEAN member states, all dental schools ideally need an agreed upon common curriculum with similar learning outcomes and competencies of the graduates. The common curriculum must be of a high standard that is comparable to international standards such as the standards for undergraduate dental curricula in Europe [2]. Because there is currently no such curriculum, learning outcomes, or competencies in the ASEAN region, developing a standard curriculum is one of the keys to success for the free movement of dental professionals across the region and will provide new graduates with the common dental competencies required for all ASEAN dentists.

Competency is "a combination of knowledge, skills, professional attitude, personal attributes, an ability to work independently (without direct supervision), and context" [3]. Competency is a primary concern in competency-based dental curriculum [4] in which the societal needs for oral healthcare, institutional factors (e.g., structures of the dental school), and national factors (e.g., educational policy, politics) are taken into account [3]. In several parts of the world (e.g., USA, Europe), a list of competencies for new dental graduates has been already developed and implemented [5,6]. However, in Southeast Asia, the common profile and competencies for ASEAN dentists have not yet been established. General competencies for dentists in any country could be similar; for example, a dentist should be able to perform a simple extraction. However, the community character, local sociocultural context, and oral health status can influence how the competencies are set up [3]. Thus, competencies for ASEAN dentists might be different from dentists in other areas outside Southeast Asia. Such competencies for ASEAN dentists, in particular, need to be identified and developed. New graduates from the ASEAN dental competencies would fulfill the purpose of facilitating the free movement of dental professionals and dentists across the Southeast Asia region.

Developing competencies for ASEAN dentists will also lead to further dental education development including standards for an undergraduate dental curriculum, quality assurance, teacher training, and collaborative research in dental education. 


\subsection{Facilitating Free Movement of Dental Professionals Across ASEAN}

\subsubsection{Current Work}

In May 2015, the Faculty of Dentistry, Chulalongkorn University, hosted the ASEAN Dental Forum (ADF) where 26 of the AJCCD members from ASEAN member states and representatives from Thai dental schools have attended and signed the Bangkok Declaration of 22 May 2015. The declaration emphasizes that ASEAN dental schools will work together, on the basis of trust and willingness, toward primary goals to achieve the harmonization of dental education across the ASEAN region by (1) developing common competencies for the safe and independent practice of ASEAN general dental practitioners and (2) developing an ASEAN undergraduate dental curriculum. Currently the harmonization of ASEAN undergraduate dental education is one part of the AJCCD work plan 2016-2020. With an agreement of the AJCCD, the Faculty of Dentistry, Chulalongkorn University, is now the leading institution responsible for conducting an international meeting (ADF) to develop major competencies for ASEAN dentists. The next ADF meeting will be held in late August 2016.

In order to improve quality and gain acceptability of the common competencies developed by the ADF, information, opinions, and agreements from stakeholders within dental education are required. As a part of the ADF, representatives from ASEAN member states (educators and policy makers) are included in the meeting panel, and a wider audience (practitioners, academics, patients) will have an opportunity to get involved in a public hearing. ASEAN students - who are directly affected by the common competencies developed by the ADF - will be invited to attend a meeting in September 2016 (after the ADF meeting) to provide the "student voice" toward creating common dental competencies for ASEAN dentists. The student representatives will provide in-depth information and critique based on their perspectives (i.e., students as consumers of dental education). The consensual agreements from student representatives will be combined with the consensual agreements from the ADF (educators and policy makers) to develop the first draft of common competencies. When the first draft is written, a public hearing will be held, before being passed on to the main AJCCD body for final approval and implementation. Then the AJCCD member from each country will pass this message to the policy makers of the ASEAN member states and start to set the time line for the new curriculum of all dental schools across ASEAN to comply with the common competencies for ASEAN dentists. As a result, there will be less concern of the quality of dentists when they cross the border for free movement of dental services as required by the MRA. 


\subsubsection{Future Work}

Only developing common competencies for ASEAN dental graduates may not fully support the free movement of dental professional across ASEAN. Future work that AJCCD and other political bodies need to focus includes four main areas:

1. The guidelines for an undergraduate dental curriculum in ASEAN emphasizing contemporary educational strategies, assessment, and credit transfer system in relation to the principles of competency-based dental education

2. Quality assurance for an undergraduate dental curriculum in ASEAN ensuring that the curriculum is developed and regularly improved in line with the ASEAN and international standards

3. Educational development policies and strategies embedding research-based education, enterprise education, public engagement, and modern educational methods (e.g., technology-enhanced learning, evidence-based practice) into the ASEAN undergraduate dental education

4. Academic training and continuing professional development for ASEAN dental educators/staff in the area of educational practice

\subsection{Conclusion}

Facilitating the free movement of dental professionals across ASEAN is not a straightforward process. This paper has summarized how the free movement of dental professionals across ASEAN was initiated and how harmonization of undergraduate dental education has been fundamental to the free movement process. The success of this process strongly relies on the mutual respect and collaboration among stakeholders especially ASEAN dental educators, students, practitioners, policy makers, and the whole ASEAN community.

\section{References}

1. ASEAN. ASEAN mutual recognition arrangement on dental practitioners. New York: The Association of Southeast Nations; 2009. http://investasean.asean.org/files/upload/MRA\%20 Dental\%20Practitioner\%20(Feb09).pdf. Accessed on 26 Aug 2016.

2. Manogue M, McLoughlin J, Christersson C, Delap E, Lindh C, Schoonheim-Klein M, et al. Curriculum structure, content, learning and assessment in European undergraduate dental education - update 2010. Eur J Dent Educ. 2011;15:133-41.

3. Chuenjitwongsa S, Oliver R, Bullock A. Competence, competency-based education, and undergraduate dental education: a discussion paper. Eur J Dent Educ. 2016. doi:10.1111/ eje.12213. 
4. Chambers DW. Competency-based dental education in context. Eur J Dent Educ. 1998;2:8-13.

5. ADEA. ADEA competencies for the new general dentist. J Dent Educ. 2010;74:765-8.

6. Cowpe J, Plasschaert A, Harzer W, Vinkka-Puhakka H, Walmsley AD. Profile and competences for the graduating European dentist - update 2009. Eur J Dent Educ. 2010;14:193-202.

Open Access This chapter is distributed under the terms of the Creative Commons Attribution 4.0 International License (http://creativecommons.org/licenses/by/4.0/), which permits use, duplication, adaptation, distribution and reproduction in any medium or format, as long as you give appropriate credit to the original author(s) and the source, provide a link to the Creative Commons license and indicate if changes were made.

The images or other third party material in this chapter are included in the work's Creative Commons license, unless indicated otherwise in the credit line; if such material is not included in the work's Creative Commons license and the respective action is not permitted by statutory regulation, users will need to obtain permission from the license holder to duplicate, adapt or reproduce the material. 